\title{
EVALUATION OF SOME EXOTIC SORGHUM LINES FOR THEIR RESISTANCE TO SESAMIA CRETICA LED. INFESTATION AND YIELDING POTENTIAL
}

\author{
MOURAD, A.E.A.A. ${ }^{1}$ and A.M.EL-RAWY ${ }^{2}$ \\ 1. Sorghum Department, Field Crops Research Institute, ARC, Giza, Egypt. \\ 2. Plant Protection Research Institute, ARC, Dokki, Giza, Egypt.
}

(Manuscript received 29 November 2011)

\begin{abstract}
The objective of the present study was to evaluate 13 exotic sorghum lines and Dorado (check variety) for their resistance to infestation by the pink stem borer Sesamia cretica under natural and artificial infestation and yielding potential during 2010 and 2011 seasons. The results revealed that two lines (ICSR-92003 and ICSB-88005) were resistant to S. cretica under natural infestation and one line (ICSR-92003) was under artificial infestation. Line ICSR-92003 possessed high resistance to this insect (18.62\% infested plants and 3.39\% dead hearts) with high yielding potential (24.08 ardab/feddan), followed by line ICSV-273 possessed moderate resistance to this insect (26.60\% infested plants and $7.81 \%$ dead hearts) with high yielding (23.14 ardab/feddan). The tallest line was ICSV-273 $(207 \mathrm{~cm})$, while earliest flowering lines (days to $50 \%$ heading) were BTX2-1, BTX409, BTXTSC20, ICSB-88015 and ICSR-92003 (70, 70, 70.5, 71 and 71 days, respectively). The heaviest grains was obtained from lines ICSR-93004, ICSR-93001 and ICSR92003 (38.98, 37.62 and $36.88 \mathrm{gm}$, respectively). The correlation coefficient between plant infestation percentage of $S$. cretica and yield was negative significant $\left(-0.5363^{*}\right)$ and between dead hearts percentage of this insect and yield was negative significant $(-0.6034)$. Line ICSR-92003 proved high resistance to S. cretica and high potentiality, while lines ICSV-273 and ICSR93001 showed moderate resistance to this insect and relatively high potentiality.
\end{abstract}

\section{INTRODUCTION}

Grain sorghum (Sorghum bicolor (L.) Moench) grows in about 350 to 400 thousand feddans in Middle and Upper Egypt. It was cultivated for a long time ago for bread making and recently for many other purposes such as green forage or grains for feeding cattles and livestock and as row material for industries.

The pink stem borer Sesamia cretica Led. is the most important pest of sorghum in Egypt. It is widely spread all over the country and attacks also other crops such as maize and sugarcane. It attacks young sorghum plants shortly after emergence devours the whorl leaves and may kill the growing plants, causing dead heart symptoms. It is also capable of infesting older plants showing leaf feeding 
symptoms and occasionally making excavating tunnels into the stems (Tantawi et. al., 1984, Tantawi et. al., 1991 a\&b, Al-Naggar et. al., 2000 a\&b, and El-Saadany et. al., 2000). Yield losses by this insect pest are mainly attributed to the decrease in number of plants per unit area at harvest because of the large number of dead hearts, increase in plant lodging causing head drops and predisposing infested plants to disease organisms. The optimal method of controlling this insect is through host-plant resistance. This method does not increase cost, does not require special equipment and does not cause environmental pollution (Tantawi et. al., 1984, Leuschner et. al., 1985, Rana et. al., 1985, Sechu-Reddy, 1985, Srivastava, 1985, Taneja et. al., 1987, Tantawi et. al., 1991 a and El-Serwy and Saba, 1993).

The present work aims for screening thirteen sorghum lines and Dorado (check variety) for their resistance to infestation by the pink stem borer $S$. cretica (under natural and artificial infestation conditions) and yielding potential.

\section{MATERIALS AND METHODS}

Field experiments were conducted at Sids Agricultural Research Station, BeniSweif Governorate during two sorghum growing seasons (2010 and 2011).

Thirteen lines of sorghum and Dorado (check variety) were obtained from sorghum Research Department, Field Crops Research Institute (FCRI), ARC and used in this study (Table 1).

Table 1. Sorghum lines tested.

\begin{tabular}{|c|l|l|l|c|l|c|l|}
\hline $\begin{array}{c}\text { Entry } \\
\text { No. }\end{array}$ & $\begin{array}{c}\text { Name and } \\
\text { pedigree }\end{array}$ & $\begin{array}{c}\text { Grain } \\
\text { color }\end{array}$ & \multicolumn{1}{|c|}{ Origin } & $\begin{array}{c}\text { Entry } \\
\text { No. }\end{array}$ & $\begin{array}{c}\text { Name and } \\
\text { pedigree }\end{array}$ & $\begin{array}{c}\text { Grain } \\
\text { color }\end{array}$ & \multicolumn{1}{|c|}{ Origin } \\
\hline 1 & BTX2-1 & Yellow & Texas (USA) & 8 & ICSR-92003 & Yellow & $\begin{array}{l}\text { ICRISAT } \\
\text { (India) }\end{array}$ \\
\hline 2 & BTX409 & Yellow & Texas (USA) & 9 & ICSR-93001 & Yellow & $\begin{array}{l}\text { ICRISAT } \\
\text { (India) }\end{array}$ \\
\hline 3 & BTX631 & White & Texas (USA) & 10 & ICSR-93002 & Yellow & $\begin{array}{l}\text { ICRISAT } \\
\text { (India) }\end{array}$ \\
\hline 5 & BTXTSC20 & Yellow & Texas (USA) & 11 & ICSR-93004 & Yellow & $\begin{array}{l}\text { ICRISAT } \\
\text { (India) }\end{array}$ \\
\hline 6 & $\begin{array}{l}\text { ICSB } \\
88005\end{array}$ & Yellow & ICRISAT(India) & 13 & 88 1080 & Yellow & $\begin{array}{l}\text { Texas (USA) } \\
\text { (India) }\end{array}$ \\
\hline 7 & $\begin{array}{l}\text { ICSB }- \\
88015\end{array}$ & Yellow & ICRISAT(India) & 14 & $\begin{array}{l}\text { Dorado(check } \\
\text { variety) }\end{array}$ & Yellow & $\begin{array}{l}\text { Nebraska } \\
\text { (USA) }\end{array}$ \\
\hline
\end{tabular}

Two field evaluation experiments were carried out. One was conducted under natural infestation of the pink stem borer S. cretica during two seasons (2010 and 2011) and the other one was conducted under artificial infestation conditions during 2011 season. 
The grains were sown on $30-6-2010$ and $28-6-2011$ for natural infestation and sown on 30-5-2011 for artificial infestation conditions. The randomized complete blocks design (RCBD) with three replicates was used. The experimental plot was four rows of $6 \mathrm{~m}$ length and $60 \mathrm{~cm}$ width, with a distance of $20 \mathrm{~cm}$ between hills and two plants per hill. No pest control was carried out in both years.

Ten plants from each plot were artificially infested with newly hatched larvae of $S$. cretica produced from Corn Borer Research Lab (CBRL), Maize Research Section, ARC, Giza, Egypt. Each plant received 8 neonate larvae of the pink stem borer which were mixed with maize cob grits and placed into the whorl of the plants ( 20 days ago from planting date) using the Bazooka as mechanical dispenser (according to Mihm, 1982). Two shots of Bazooka were used on each plant; each shot delivered 4 larvae.

\section{Data recorded:}

\section{In the field under natural infestation:}

The following traits were measured after 30 and 45 days from planting date.

\section{1- Percentage of infested plants (IP\%) as follows:}

$$
\text { IP\% }=\frac{\text { No. of infested plants / plot }}{\text { Total No. of plants / plot }} \times 100
$$

Lines were classified according to their mean IP\% into: resistance (Less than $35 \%)$, moderately resistance (35\% to less than $70 \%)$ and susceptible ( $70 \%$ or above) according to Al-Naggar et al (2000b).

\section{2- Percentage of dead hearts (DH\%) as follows:}

$$
\mathrm{DH} \%=\frac{\text { No. of dead hearts / plot }}{\text { Total No. of plants / plot }} \times 100
$$

Lines were classified according to their mean $\mathrm{DH} \%$ into : resistance (less than $7 \%)$, moderately resistance ( $7 \%$ to less than $15 \%)$ and susceptible ( $15 \%$ or more) according to Al-Naggar et al (2000b).

\section{In the field under artificial infestation:}

The following traits were measured after 15 days from artificial infestation.

\section{1- Percentage of infested plants (IP\%) as follows:}

$$
\text { IP\% }=\frac{\text { No. of infested plants / plot }}{\text { No. of artificially infested plants / plot }} \times 100
$$

Lines were classified according to their mean IP\% as the same ranks mentioned before, according to Al-Naggar et al (2000a).

\section{2- Percentage of dead hearts (DH\%) as follows:}

$$
\mathrm{DH} \%=\frac{\text { No. of dead hearts / plot }}{\text { No. of artificially infested plants / plot }} \times 100
$$


Lines were classified according to their mean $\mathrm{DH} \%$ as mentioned before , according to Al-Naggar et al (2000a).

As for the agronomic characters, plant height $(\mathrm{cm})$, days needed for $50 \%$ heading, 1000-grain weight ( $\mathrm{gm}$ ) and grain yield per feddan (ardab) were also recorded.

The data were statistically analyzed according to Snedecor and Cochran (1981) and treatment means were compared by the least significant difference (L.S.D) at $5 \%$ level of probability.

\section{RESULTS AND DISCUSSION}

\section{1- Field evaluation of sorghum lines resistance to $\boldsymbol{S}$. cretica under natural infestation and yielding potential:}

a- Means of attributes expressing resistance to $S$. cretica:

The obtained results for each of the thirteen exotic sorghum lines and Dorado (check variety) under natural infestation during 2010 and 2011 seasons and combined across the two years are presented in Tables (2 and 4).

\section{a.1- Infested plants (IP):}

The combined data across the two years indicated that, ten resistance lines were detected (ICSR-92003, ICSB-88005, ICSR-93004, ICSV-273， ICSR-93001, BTX409, BTX631，BTX2-1，ICSR-93002 and ICSB-37) with an average of (18.62, $24.13,25.93,26.60,27.18,29.47,29.61,31.10,31.43$ and $32.84 \%$, respectively) and three moderately resistant lines (BTXTSC20, ICSB-88015 and 88V1080) with an average of (41.70, 47.68 and $53.37 \%$, respectively) and also, the variety Dorado was moderately resistance with an average of $40.59 \%$.

\section{a.2- Dead hearts (DH):}

Combined data across the two in the same table showed that, $\mathrm{DH}$ average across the two years ranged from $3.39 \%$ for ICSR-92003 to $20.85 \%$ for $88 \mathrm{~V} 1080$. Combined data showed also that, two lines (ICSR-92003 and ICSB-88005) with an average of 3.39 and $6.39 \%$, respectively, were considered as resistant to $S$. cretica, eight lines and Dorado variety were moderately resistant (ICSR-93004, ICSR-93001, ICSV-273, BTX2-1, BTX631，ICSR-93002, BTX409, ICSB-37 and Dorado variety) with an average of $7.42,7.50,7.81,7.93,8.90,9.42,11.25,12.08$ and $12.10 \%$, respectively and three lines were susceptible lines (BTXTSC20, ICSB-88015 and $88 \mathrm{~V} 1080$ ) with dead hearts average of $16.51,20.46$ and $20.85 \%$, respectively.

\section{b- Yield and yield components:}

The performance of the lines evaluated in the two successive growing seasons and the combined analysis are presented in Tables 3 and 4. There were significant differences among the lines in all characters. 
The tallest line was ICSV-273 $(207 \mathrm{~cm})$ followed by ICSR-92003 and ICSR-93002 (170.8 and $170.0 \mathrm{~cm}$, respectively). While earliest flowering lines (days to $50 \%$ heading) were BTX2-1 and BTX409 (70 days), followed by BTXTSC20 (70.5 days), ICSB-88015 and ICSR-92003 (71 days). 1000-grain weight, lines ICSR-93004, ICSR-93001, ICSR92003 and ICSR-93002 were 38.98, 37.62, 36.88 and 35.58gm, respectively. These lines produced significantly heavier grains compared with the check variety (Dorado with $31.55 \mathrm{gm})$. The results grain yield showed that lines ICSR-92003 and ICSV-273 had the first rank in this respect ( 24.08 and 23.14 ardab/fed., respectively) followed by lines ICSR-93001, ICSR-93004 and ICSR-93002 being 20.53, 19.72 and 18.09 ardab/fed., respectively. While the check variety produced $17.09 \mathrm{ardab} / \mathrm{fed}$. These results are in agreement with those obtained by Latif (1999), Mourad et al (1999) and Mourad and Anton (2007).

\section{2- Field evaluation of sorghum lines resistance to infestation by $S$. cretica under artificial infestation:}

\section{1- Infested plants (IP):}

Data in Table (5) showed that, one resistance line (ICSR-92003) with an average of $32.67 \%$ infested plants, nine moderately resistant lines (ICSB-88005, ICSR-93004，ICSV-273，ICSR-93001，BTX2-1，BTX409，ICSR-93002，BTX631 and ICSB-37) with an average of $(46.84,47.00,48.33,51.67,53.10,58.33,62.67,63.00$ and $63.33 \%$, respectively) and four susceptible lines (Dorado, BTXTSC20, 88V1080 and ICSB-88015) with an infestation average of $(71.67,72.50,72.67$ and $76.00 \%$, respectively).

\section{2- Dead hearts (DH):}

The results in Table (5) indicated that, one resistance line (ICSR-92003) with an average of $6.00 \%$, four moderately resistant lines (ICSR-93004, ICSR-93001, ICSB88005 and ICSV-273) with an average of (12.67, 13.33, 14.33 and 14.67\%, respectively) and eight susceptibility lines (BTX2-1, BTX631, BTX409, ICSR-93002, ICSB-37, BTXTS20, ICSB-88015 and 88V1080) with an average of (18.33, 20.00, $20.67,23.33,25.00,35.47,40.00$ and $46.67 \%$, respectively) and also, the variety Dorado was susceptible with an average of $26.67 \%$. Al-Naggar et. al., 2000 a recorded maize genotypic differences resistance to the pink stem borer $S$. cretica under artificial infestation.

A short glance to the data in Table (4) reveals that, the correlation coefficient between infested plant percentage of $S$. cretica and yield was negative significant ($\left.0.5363^{*}\right)$. Also, the correlation coefficient between dead hearts percentage for this insect and yield was negative significant $(-0.6034 *)$. One line ICSR-92003 proved high resistance to $S$. cretica and at the same time higher grain yield (24.08 ardab/fed.) and two lines ICSV-273 and ICSR-93001 proved moderate resistance to this insect and relatively high grain yield (23.14 and $20.53 \mathrm{ardab} /$ fed., respectively). 
Table 2. Average of infested plants (IP) and dead hearts (DH) percentages under natural infestation with $S$. cretica during two successive growing seasons $(2010-2011)$ and the combined analysis.

\begin{tabular}{|c|c|c|c|c|c|c|c|c|c|c|c|c|c|}
\hline \multirow{3}{*}{$\begin{array}{c}\text { Entry } \\
\text { No. }\end{array}$} & \multirow{3}{*}{ Lines name } & \multicolumn{6}{|c|}{ IP } & \multicolumn{6}{|c|}{$\mathrm{DH}$} \\
\hline & & \multicolumn{2}{|c|}{2010} & \multicolumn{2}{|c|}{2011} & \multicolumn{2}{|c|}{ Combined } & \multicolumn{2}{|c|}{2010} & \multicolumn{2}{|c|}{2011} & \multicolumn{2}{|c|}{ Combined } \\
\hline & & $\%$ & Reaction & $\%$ & Reaction & $\%$ & Reaction & $\%$ & Reaction & $\%$ & Reaction & $\%$ & Reaction \\
\hline 1 & BTX2-1 & $31.91 \mathrm{~d}$ & $\mathrm{R}$ & 30.28def & $\mathrm{R}$ & $31.10 \mathrm{~d}$ & $\mathrm{R}$ & 8.34cde & $M$ & $7.51 \mathrm{bcd}$ & $M$ & 7.93cde & $M$ \\
\hline 2 & BTX409 & 27.83de & $\mathrm{R}$ & 31.11cdef & $\mathrm{R}$ & 29.47de & $\mathrm{R}$ & $11.39 \mathrm{~cd}$ & $M$ & $11.11 \mathrm{abc}$ & $M$ & $11.25 \mathrm{~cd}$ & $M$ \\
\hline 3 & BTX631 & $30.84 d$ & $\mathrm{R}$ & $28.38 \mathrm{ef}$ & $\mathrm{R}$ & 29.61de & $\mathrm{R}$ & 8.96cde & $M$ & $8.83 \mathrm{bcd}$ & $M$ & $8.90 \mathrm{~cd}$ & $M$ \\
\hline 4 & BTXTSC20 & $44.04 \mathrm{bc}$ & $M$ & $39.35 \mathrm{bcd}$ & $M$ & $41.70 \mathrm{~b}$ & $M$ & 17.61ab & $\mathrm{S}$ & $15.40 \mathrm{ab}$ & $S$ & $16.51 \mathrm{ab}$ & $\mathrm{S}$ \\
\hline 5 & ICSB-37 & $30.58 \mathrm{~d}$ & $\mathrm{R}$ & 35.10 bcde & M & $32.84 \mathrm{~cd}$ & $\mathrm{R}$ & $12.60 \mathrm{bc}$ & M & $11.56 \mathrm{abc}$ & M & $12.08 \mathrm{bc}$ & $M$ \\
\hline 6 & ICSB-88005 & 26.23de & $\mathrm{R}$ & $22.03 \mathrm{fg}$ & $\mathrm{R}$ & 24.13ef & $\mathrm{R}$ & $6.50 \mathrm{de}$ & $\mathrm{R}$ & $6.28 \mathrm{bcd}$ & $\mathrm{R}$ & 6.39de & $\mathrm{R}$ \\
\hline 7 & ICSB-88015 & $51.19 a b$ & M & $44.17 a b$ & M & 47.68ab & M & $21.38 a$ & $\mathrm{~S}$ & $19.53 a$ & $S$ & $20.46 a$ & $\mathrm{~S}$ \\
\hline 8 & ICSR-92003 & $21.14 \mathrm{e}$ & $\mathrm{R}$ & $16.10 \mathrm{~g}$ & $\mathrm{R}$ & $18.62 f$ & $\mathrm{R}$ & $5.38 \mathrm{e}$ & $\mathrm{R}$ & $1.39 d$ & $\mathrm{R}$ & $3.39 \mathrm{e}$ & $\mathrm{R}$ \\
\hline 9 & ICSR-93001 & 28.63de & $\mathrm{R}$ & 25.72efg & $\mathrm{R}$ & 27.18def & $\mathrm{R}$ & 8.71cde & $M$ & $6.29 \mathrm{~cd}$ & $\mathrm{R}$ & 7.50cde & $M$ \\
\hline 10 & ICSR-93002 & $31.48 \mathrm{~d}$ & $\mathrm{R}$ & $31.38 \mathrm{cdef}$ & $\mathrm{R}$ & $31.43 \mathrm{de}$ & $\mathrm{R}$ & 10.11cde & $M$ & $8.72 \mathrm{bcd}$ & $M$ & $9.42 \mathrm{~cd}$ & $M$ \\
\hline 11 & ICSR-93004 & 24.63de & $\mathrm{R}$ & 27.22ef & $\mathrm{R}$ & 25.93def & $\mathrm{R}$ & 8.31cde & M & $6.53 \mathrm{bcd}$ & $\mathrm{R}$ & 7.42cde & M \\
\hline 12 & ICSV-273 & 27.29de & $\mathrm{R}$ & 25.91efg & $\mathrm{R}$ & $26.60 \mathrm{def}$ & $\mathrm{R}$ & $8.10 \mathrm{cde}$ & M & $7.52 \mathrm{bcd}$ & M & 7.81cde & $M$ \\
\hline 13 & $88 \mathrm{~V} 1080$ & $56.16 a$ & M & 50.58a & M & $53.37 a$ & M & $22.05 a$ & $\mathrm{~S}$ & $19.65 a$ & $\mathrm{~S}$ & $20.85 a$ & $\mathrm{~S}$ \\
\hline 14 & Dorado & $40.81 \mathrm{c}$ & $M$ & $40.37 \mathrm{bc}$ & $M$ & $40.59 b c$ & $M$ & $12.27 \mathrm{bc}$ & $M$ & $11.93 a b c$ & $M$ & $12.10 \mathrm{bc}$ & $M$ \\
\hline & LSD 0.05\% & 7.68 & - & 9.85 & - & 8.70 & - & 5.51 & - & 8.94 & - & 5.13 & - \\
\hline
\end{tabular}

$\mathrm{R}=$ resistant $\quad \mathrm{M}=$ moderate $\quad \mathrm{S}=$ susceptible

Means followed by the same letter (s) in each column within each treatment are not significant. 
Table 3. Performance of thirteen exotic sorghum lines and Dorado (check variety) during two seasons (2010 - 2011) and the combined analysis.

\begin{tabular}{|c|c|c|c|c|c|c|c|c|c|c|c|c|c|}
\hline \multirow{2}{*}{$\begin{array}{c}\text { Entry } \\
\text { No. }\end{array}$} & \multirow{2}{*}{ Lines name } & \multicolumn{3}{|c|}{ Plant height $(\mathrm{cm})$} & \multicolumn{3}{|c|}{ Days to $50 \%$ heading } & \multicolumn{3}{|c|}{1000 -grain Wt (gm) } & \multicolumn{3}{|c|}{ Yield / fed. (ardab)* } \\
\hline & & 2010 & 2011 & Combined & 2010 & 2011 & Combined & 2010 & 2011 & Combined & 2010 & 2011 & Combined \\
\hline 1 & BTX2-1 & $115.0 \mathrm{e}$ & $125.0 \mathrm{~d}$ & $120.0 \mathrm{f}$ & $70 c$ & $70 \mathrm{bc}$ & $70 \mathrm{e}$ & 29.07def & $27.91 \mathrm{~cd}$ & $28.49 \mathrm{def}$ & $10.57 \mathrm{f}$ & 9.82efg & $10.20 \mathrm{gh}$ \\
\hline 2 & BTX409 & 127.3de & $131.7 d$ & 129.5def & $71 \mathrm{bc}$ & $69 c$ & $70 \mathrm{e}$ & $32.77 \mathrm{cde}$ & $26.43 d$ & 29.60cde & $12.63 \mathrm{ef}$ & $8.18 \mathrm{gh}$ & $10.40 \mathrm{gh}$ \\
\hline 3 & BTX631 & 125.0de & $130.0 \mathrm{~d}$ & $127.5 \mathrm{ef}$ & $75 a b c$ & $73 a$ & $74 a b c$ & $33.33 \mathrm{~cd}$ & $28.22 \mathrm{~cd}$ & $30.78 \mathrm{~cd}$ & $19.81 \mathrm{bcd}$ & $9.70 \mathrm{fg}$ & $14.76 \mathrm{ef}$ \\
\hline 4 & BTXTSC20 & $148.3 \mathrm{bc}$ & $136.7 \mathrm{~cd}$ & $142.5 \mathrm{cde}$ & $71 \mathrm{bc}$ & $70 \mathrm{bc}$ & $70.5 \mathrm{de}$ & $35.36 \mathrm{bcd}$ & $27.19 \mathrm{~d}$ & $31.28 \mathrm{c}$ & $10.38 \mathrm{f}$ & $6.50 \mathrm{~h}$ & $8.44 \mathrm{~h}$ \\
\hline 5 & ICSB-37 & $126.7 d$ & $128.3 d$ & $127.5 \mathrm{ef}$ & $77 a b$ & $74 a$ & $75.5 a b$ & $26.38 \mathrm{f}$ & $25.79 d$ & $26.09 \mathrm{fg}$ & $12.75 \mathrm{ef}$ & 12.22de & $12.49 \mathrm{fg}$ \\
\hline 6 & ICSB-88005 & $145.0 \mathrm{bcd}$ & $153.3 \mathrm{bcd}$ & $149.2 \mathrm{bcde}$ & $79 a$ & $74 a$ & $76.5 a b$ & $28.44 \mathrm{ef}$ & $21.15 \mathrm{e}$ & $24.80 \mathrm{~g}$ & 14.00def & $11.00 \mathrm{ef}$ & $12.50 \mathrm{fg}$ \\
\hline 7 & ICSB-88015 & $158.3 \mathrm{bc}$ & $150.0 \mathrm{bcd}$ & $154.2 b c$ & $72 b c$ & $70 b c$ & 71cde & $26.40 \mathrm{f}$ & $26.24 d$ & $26.32 \mathrm{fg}$ & $10.23 \mathrm{f}$ & $7.02 \mathrm{~h}$ & $8.63 \mathrm{~h}$ \\
\hline 8 & ICSR-92003 & $165.0 \mathrm{bc}$ & $176.7 a b$ & $170.8 \mathrm{~b}$ & $71 \mathrm{bc}$ & $71 a b c$ & 71cde & $40.69 a$ & $33.06 a b$ & $36.88 a b$ & $27.32 \mathrm{a}$ & $20.84 a$ & $24.08 \mathrm{a}$ \\
\hline 9 & ICSR-93001 & $160.0 \mathrm{bc}$ & $156.7 \mathrm{bcd}$ & $158.3 b c$ & $74 a b c$ & $73 a b$ & $73.5 \mathrm{bcd}$ & $40.83 a$ & $34.40 a b$ & $37.62 a b$ & $22.01 \mathrm{abc}$ & 19.05ab & $20.53 b c$ \\
\hline 10 & ICSR-93002 & $173.3 b$ & 166.7bc & $170.0 \mathrm{~b}$ & $75 a b c$ & $71 a b c$ & 73bcde & $38.94 a b$ & $32.22 b$ & $35.58 \mathrm{~b}$ & $18.00 \mathrm{cde}$ & $18.17 \mathrm{~b}$ & $18.09 \mathrm{~cd}$ \\
\hline 11 & ICSR-93004 & $148.3 \mathrm{bcd}$ & $141.7 \mathrm{~cd}$ & $145.0 \mathrm{cde}$ & $77 a b$ & $73 a b$ & $75 a b$ & $42.43 a$ & $35.52 \mathrm{a}$ & $38.98 a$ & $20.99 a b c$ & $18.45 \mathrm{ab}$ & $19.72 \mathrm{~cd}$ \\
\hline 12 & ICSV-273 & $210.7 a$ & $203.3 a$ & $207.0 a$ & $79 a$ & 73ab & $76 a b$ & $28.44 \mathrm{ef}$ & $27.05 d$ & $27.75 \mathrm{ef}$ & 25.88ab & 20.39ab & 23.14ab \\
\hline 13 & $88 \mathrm{~V} 1080$ & $138.3 \mathrm{cde}$ & $145.0 \mathrm{bcd}$ & $141.7 \mathrm{cdef}$ & $80 a$ & $74 a$ & $77 a$ & $26.07 f$ & $25.76 \mathrm{~d}$ & $25.92 \mathrm{fg}$ & $13.85 \mathrm{def}$ & $14.96 \mathrm{c}$ & $14.41 \mathrm{ef}$ \\
\hline 14 & Dorado & $148.3 \mathrm{bcd}$ & $149.0 \mathrm{bcd}$ & $148.7 \mathrm{~cd}$ & $76 a b c$ & $73 a b$ & $74.5 a b$ & 32.71cde & $30.38 \mathrm{bc}$ & $31.55 \mathrm{c}$ & $19.89 \mathrm{bcd}$ & $14.28 \mathrm{~cd}$ & 17.09de \\
\hline & SD $0.05 \%$ & 28.92 & 33.76 & 21.80 & 6.50 & 3.09 & 3.31 & 4.75 & 3.19 & 2.79 & 6.50 & 2.51 & 3.41 \\
\hline
\end{tabular}

Means followed by the same letter (s) in each column within each treatment are not significant.

$*$ Fed. $=4200 \mathrm{~m}^{2} \quad$ Ardab $=140 \mathrm{~kg}$. 
Table 4. Relationship between sorghum lines infestation with $S$. cretica and yield (Combined).

\begin{tabular}{|c|c|c|c|c|c|c|}
\hline \multirow{3}{*}{$\begin{array}{l}\text { Entry } \\
\text { No. }\end{array}$} & \multirow{3}{*}{ Lines name } & \multicolumn{4}{|c|}{ Infestation with $S$. cretica } & \multirow{3}{*}{$\begin{array}{l}\text { Yield/Fed } \\
\text { (ardab)* }\end{array}$} \\
\hline & & \multicolumn{2}{|c|}{ Infested plant } & \multicolumn{2}{|c|}{ Dead hearts } & \\
\hline & & $\%$ & Reaction & $\%$ & Reaction & \\
\hline 1 & BTX2-1 & $31.10 \mathrm{~d}$ & $\mathrm{R}$ & 7.93cde & $M$ & $10.20 \mathrm{gh}$ \\
\hline 2 & BTX409 & 29.47de & $\mathrm{R}$ & $11.25 \mathrm{~cd}$ & $M$ & $10.40 \mathrm{gh}$ \\
\hline 3 & BTX631 & 29.61de & $\mathrm{R}$ & $8.90 \mathrm{~cd}$ & $M$ & $14.76 \mathrm{ef}$ \\
\hline 4 & BTXTSC20 & $41.70 \mathrm{~b}$ & M & $16.51 a b$ & $S$ & $8.44 \mathrm{~h}$ \\
\hline 5 & ICSB-37 & $32.84 \mathrm{~cd}$ & $\mathrm{R}$ & $12.08 \mathrm{bc}$ & $M$ & $12.49 \mathrm{fg}$ \\
\hline 6 & ICSB-88005 & 24.13ef & $\mathrm{R}$ & 6.39de & $\mathrm{R}$ & $12.50 \mathrm{fg}$ \\
\hline 7 & ICSB-88015 & $47.68 \mathrm{ab}$ & $M$ & $20.46 a$ & $\mathrm{~S}$ & $8.63 \mathrm{~h}$ \\
\hline 8 & ICSR-92003 & $18.62 f$ & $\mathrm{R}$ & $3.39 \mathrm{e}$ & $\mathrm{R}$ & $24.08 a$ \\
\hline 9 & ICSR-93001 & 27.18def & $\mathrm{R}$ & 7.50cde & $M$ & $20.53 \mathrm{bc}$ \\
\hline 10 & ICSR-93002 & 31.43de & $\mathrm{R}$ & $9.42 \mathrm{~cd}$ & $M$ & $18.09 \mathrm{~cd}$ \\
\hline 11 & ICSR-93004 & 25.93def & $\mathrm{R}$ & 7.42cde & M & $19.72 \mathrm{~cd}$ \\
\hline 12 & ICSV-273 & 26.60def & $\mathrm{R}$ & 7.81cde & M & $23.14 a b$ \\
\hline 13 & $88 \mathrm{~V} 1080$ & $53.37 a$ & M & $20.85 a$ & $\mathrm{~S}$ & $14.41 \mathrm{ef}$ \\
\hline 14 & Dorado & $40.59 \mathrm{bc}$ & M & $12.10 \mathrm{bc}$ & M & 17.09de \\
\hline \multicolumn{2}{|c|}{ LSD $0.05 \%$} & 8.70 & - & 5.13 & - & 3.41 \\
\hline \multicolumn{6}{|c|}{ Correlation coefficient between Infested plant $\%$ and yield } & $-0.5363^{*}$ \\
\hline \multicolumn{6}{|c|}{ Correlation coefficient between Dead hearts $\%$ and yield } & $-0.6034 *$ \\
\hline
\end{tabular}

$\mathrm{R}=$ resistant $\quad \mathrm{M}=$ moderate $\quad \mathrm{S}=$ susceptible

Means followed by the same letter (s) in each column within each treatment are not significant.

* Fed. $=4200 \mathrm{~m}^{2}$

$\operatorname{Ardab}=140 \mathrm{~kg}$. 
Table 5. Average infested plants and dead hearts percentages for thirteen sorghum lines and Dorado as a check variety under artificial infestation with $S$. cretica in 2011 season.

\begin{tabular}{|c|l|c|c|c|c|}
\hline \multirow{2}{*}{$\begin{array}{c}\text { Entry } \\
\text { No. }\end{array}$} & \multirow{2}{*}{ Lines name } & \multicolumn{4}{|c|}{ Infestation with S. cretica } \\
\cline { 3 - 6 } & & \multicolumn{2}{|c|}{ Infested plant } & \multicolumn{2}{c|}{ Dead hearts } \\
\cline { 3 - 6 } & & $\%$ & Reaction & $\%$ & Reaction \\
\hline 1 & \multirow{2}{*}{ BTX2-1 } & $53.10 \mathrm{~cd}$ & $\mathrm{M}$ & $18.33 \mathrm{de}$ & $\mathrm{S}$ \\
\hline 2 & BTX409 & $58.33 \mathrm{~cd}$ & $\mathrm{M}$ & $20.67 \mathrm{de}$ & $\mathrm{S}$ \\
\hline 3 & BTX631 & $63.00 \mathrm{bc}$ & $\mathrm{M}$ & $20.00 \mathrm{de}$ & $\mathrm{S}$ \\
\hline 4 & BTXTSC20 & $72.50 \mathrm{ab}$ & $\mathrm{S}$ & $35.47 \mathrm{bc}$ & $\mathrm{S}$ \\
\hline 5 & ICSB-37 & $63.33 \mathrm{bc}$ & $\mathrm{M}$ & $25.00 \mathrm{~cd}$ & $\mathrm{~S}$ \\
\hline 6 & ICSB-88005 & $46.84 \mathrm{de}$ & $\mathrm{M}$ & $14.33 \mathrm{ef}$ & $\mathrm{M}$ \\
\hline 7 & ICSB-88015 & $76.00 \mathrm{a}$ & $\mathrm{S}$ & $40.00 \mathrm{ab}$ & $\mathrm{S}$ \\
\hline 8 & ICSR-92003 & $32.67 \mathrm{f}$ & $\mathrm{R}$ & $6.00 \mathrm{f}$ & $\mathrm{R}$ \\
\hline 9 & ICSR-93001 & $51.67 \mathrm{~cd}$ & $\mathrm{M}$ & $13.33 \mathrm{ef}$ & $\mathrm{M}$ \\
\hline 10 & ICSR-93002 & $62.67 \mathrm{bc}$ & $\mathrm{M}$ & $23.33 \mathrm{de}$ & $\mathrm{S}$ \\
\hline 11 & ICSR-93004 & $47.00 \mathrm{de}$ & $\mathrm{M}$ & $12.67 \mathrm{ef}$ & $\mathrm{M}$ \\
\hline 12 & ICSV-273 & $48.33 \mathrm{de}$ & $\mathrm{M}$ & $14.67 \mathrm{ef}$ & $\mathrm{M}$ \\
\hline 13 & $88 V 1080$ & $72.67 \mathrm{ab}$ & $\mathrm{S}$ & $46.67 \mathrm{a}$ & $\mathrm{S}$ \\
\hline 14 & Dorado & $71.67 \mathrm{ab}$ & $\mathrm{S}$ & $26.67 \mathrm{~cd}$ & $\mathrm{~S}$ \\
\hline & LSD 0.05\% & 12.65 & - & 11.04 & - \\
\hline
\end{tabular}

$\mathrm{R}=$ resistant 


\section{REFERENCES}

1. Al-Naggar, A.M., A.A. El-Ganayni, M.A. El-Lakany, H.Y. El-Sherbeiny and M.S.M. Soliman .2000a. Mode of inheritance of maize resistance to the pink stem borer Sesamia cretica Led. Under artificial infestation. Egypt. J. Plant. Breed. 4 : 13-35.

2.

$.2000 \mathrm{~b}$. Effectiveness of natural infestation in estimating genetic parameters conditioning the inheritance of maize resistance to Sesomia cretica Led. Egypt. J. Plant Breed. 4: 37-53.

3. El-Saadany, G.B., A.A. Amin, M.A. Salem and A.M. Salman .2000. Cultivation dates in relation to four major insect pests attacking sorghum in Upper Egypt. Egypt. J. Agric. Res. 78 (5): 1937-1957.

4. El-Serwy, S.A. and M.A. Saba .1993. Evaluation of certain sorghum varieties for susceptibility to infestation with the pink stalk borer Sesamia cretica Led. (Lepidoptera : Noctuidae) at Aswan Governorate. Bull. Ent. Soc. Egypt. 71: 55-59.

5. Latif, S.J. 1999. Performance of some tolerant and susceptible restorer lines of grain sorghum for drought tolerance. Egypt. J. Appl. Sci. 14 (10): 156-164.

6. Leuschner, K., S.L. Taneja and H.C. Sharma .1985. The role of plant resistance in pest management in sorghum in India. Insect Sci and its Appl. 6: 453-460.

7. Mihm, J.A. .1982. Techniques for efficient mass rearing and infestation in screening for host plant resistance to corn earworm, Heliothis zea. CIMMYT, ElBatan, Mexico, 16pp.

8. Mourad, A.E.A.A. and N.A. Anton .2007. Response of some grain sorghum genotypes to water stress under sandy soil conditions. Annals Agric. Sci., Moshtohor. 45 (4): 1305-1324.

9. ---------------, M.M. El-Menshawi and K.T. El-Afandi .1999. Morphological, yield and yield components response of some grain sorghum genotypes to salinity. Egypt. J. Appl. Sci. 14 (2): 99-109.

10. Rana, B.S., B.V. Singh and N.G.P. Rao .1985. Breeding for shootfly and stem borer resistant in sorghum. in Proceeding of the International Sorghum Entomology Workshop. 15-21 Jul 1985, College station, Texas, USA : 347-360.

11. Sechu-Reddy, K.V.1985. Relative susceptibility and resistance of some sorghum lines to stem borers in Western Kenya. Insect Sci. Appl. 6(3): 401-404.

12. Snedecor, G.W. and W.G. Cochran .1981. Statistical Methods. Seventh Ed., Iowa State Univ. Press, Ames. Iowa, USA. 
13. Srivastava, K.P.1985. Screening for sorghum stem borer resistance. in Proceeding of the International Sorghum Entomology Workshop, 15-21 Jul 1985, College Station, Texas, USA : 189-200.

14. Taneja, S.L., B.L. Agrawal and V.K. Henry .1987. Host plant resistance to sorghum stem borer. Fresented at the All India coordinated sorghum Improvement Project Workshop, 25-27 May 1987, Marathwada Agric. Univ., Parhani, Maharashta, India.

15. Tantawi, A.M., E.M.A. El-Monem, K.A. Mowafy and G.A. Ekladious .1991a. Evaluation of certain sorghum varieties for resistance against the pink stalk borer Sesamia cretica Led. Proc. $4^{\text {th }}$ Arab Cong. of the Plant Protection ARE Cairo Dec. : 430-435.

16. -------, M.F. El-Metwally, K.A. Mowafy and A.M. Soliman .1991b. Sorghum borer Sesamia cretica Led. infestation in relation to certain cultural practices including planting date, nitrogen rates and planting spacing. Proc. $4^{\text {th }}$ Arab Cong. of Plant Protection ARE Cairo Dec. : 424-429.

17. -----------, R.M. Shuman and A.G. Ali.1984. Studies on the relative susceptibility of certain sorghum varieties and strains to the pink borer, Sesamia cretica Led. Infestation. Proc. $2^{\text {nd }}$ Gen. Conf., ARC, Giza, 9-11 April, Vol. III: 66. 


\section{تقييم بعض السلالات المستوردة للأرة الرفيعة للمقاومة للإصابة بحشرة دودة القصب الكبيرة وكمية المحصول}

$$
\begin{aligned}
& \text { أحمد الرفاعي عبد العظيم أحمد مراد } 1 \text { ،عادل محمد الراوي } 2 \\
& \text { 1- قسم الذرة الرفيعة - معهُ بحوث الدحاصيل الحقلية - مركز البحوث الزراعية - جيزة - مصر. }
\end{aligned}
$$

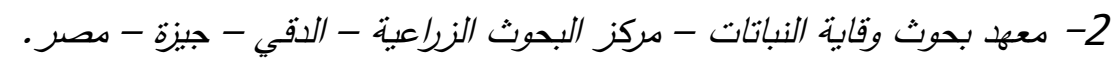

تهدف الدراسة الحالية إلى تقييم ثلاثة عشر سالمة مستوردة للذرة الرفيعة بالمقارنة بالصنف التجاري

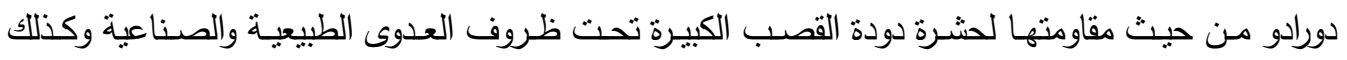

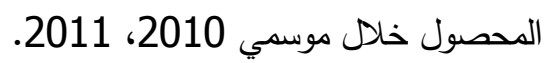

بينت النتائج المتحصل عليها أن السـلالتين ICSB-88005， ICSR-92003 كانتا مقاومتنين لدودة القصب الكبيرة تحت ظروف العدوى الطبيعيـة وأن السـلالة ICSR-92003 كانت مقاومـة لهذه الحشرة تحت ظروف العدوى الصناعية. أظهرت السـلالة ICSR-92003 مقاومـة عاليـة لدودة القصب الصب الكبيرة (18.62\% نباتات مصابة و3.39\% قلوب ميتة) وكذلك تفوقت من حيث محصول الحبوب (24.08 أردب/فدان) بالمقارنـة بالصنف التجـاري (Dorado)، في حين أظهرت السـالدة

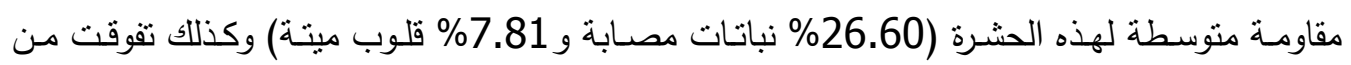
حيث محصول الحبوب (23.14 أردب/فدان) بالمقارنة بالصنف التجاري.

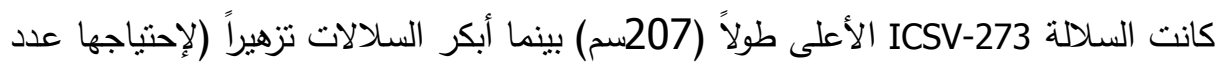

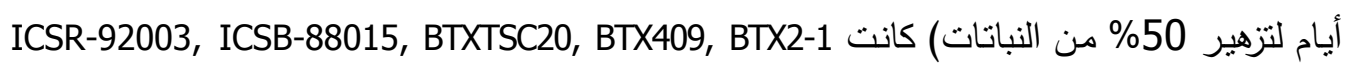

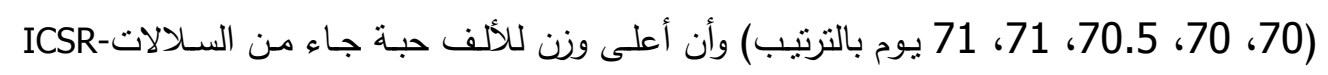
93004

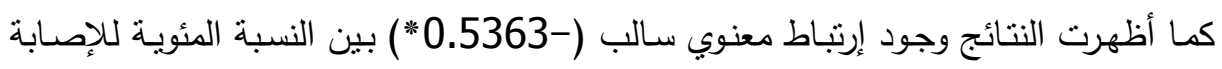
بدودة القصب الكبيرة والمحصول وكذلك إرتباط معنوي سالب (-0.6034*) بين القلوب الميتة الناتجة عن الإصابة بدودة القصب الكبيرة والمحصول.

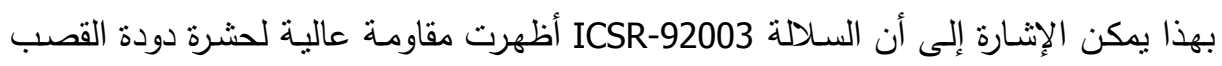
الكبيرة وكذلك أعطت أعلى محصولاً في حين أظهرت السـلالتين ICSV-273، متوسطة لهذه الحشرة وأعطت محصولاً عاليا نسبيا. 